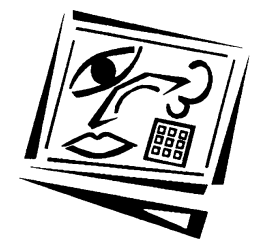

\title{
Do undergraduate paramedic students embrace case based learning using a blended teaching approach? A 3-year review
}

\author{
Brett Williams \\ Monash University
}

\begin{abstract}
This paper presents the results of a descriptive longitudinal study which aimed to identify student paramedic perceptions of case based learning used in the clinical curriculum of the Bachelor of Emergency Health (BEH) degree at Monash University, Victoria, Australia. Case based learning and its integration within clinical curriculum is an important part of undergraduate paramedic education at Monash University. The study used self reporting questionnaires involving 247 students. The analysis provides an indication of the students' perceptions of case based learning in their clinical curricula during the 2005-2007 academic years. Quantitative and qualitative data produced encouraging student satisfaction scores and themes emphasising that case based learning was an appropriate, valuable teaching and learning approach. The data also highlighted that improvements are required surrounding student equity and communication between peers and lecturing staff.
\end{abstract}

\begin{abstract}
Aims
The BEH degree is a pre-employment (pre-registration), professionally oriented, undergraduate degree that is offered on a full time on campus basis by Monash University, Melbourne, Australia. The aim of the study was to assess BEH students' perceptions and attitudes as participants in a case based learning process. The study also intended to investigate the pedagogical application of case based learning in a blended learning environment. For the purposes of this paper, blended learning is characterised by combining online teaching and learning with face to face instruction (Reay, 2001).
\end{abstract}

\section{Background}

Whilst extensive research has explored clinical teaching and learning in other disciplines such as medicine, nursing, physiotherapy and dentistry, very little literature exists on case based learning or problem based learning (PBL) within the context of paramedic education. The expansion of paramedic education from both historical and current vocational methods in Australia creates a basis for a study that seeks to develop new understandings in this important emerging area of health care education.

Case-based learning is one of several PBL fusions (others include patient centred learning) that are modelled upon a student centred philosophy. As case based learning is derived from PBL, and as such has similar characteristics (working in small groups and independent study, etc), reference throughout the paper will include both 
approaches. These teaching and learning methodologies are conceptually supported by the same educational theories used in PBL, influenced by Dewey (1916), Piaget (1968), Bruner (1966), and Vygotsky (1978) and based upon cognitivism, constructivism and perceptions of social learning relationships. The basis for these theoretical frameworks allows students to discover learning that is meaningful to them, whilst scaffolding and constructing new information based on their new learning structures and resources provided by the teacher. The learning environment promotes an autonomous learning stance for students and allows teachers to encourage students to take responsibility for their learning. It also shifts the responsibilities of teachers, who now take an active role in listening and facilitating, not interrupting and directing the students, but instead providing sound advice and guidance with learning resources (Albanese, 2000).

The case based learning process used by the author has been adapted and modified from the Maastricht Problem Based Learning 'Seven-Jump' Process, summarised in the following terms:

1. Small tutorial groups are formed

2. The clinical case or scenario is established to develop self discovery processes

3. The clinical case is then analysed and assimilated

4. Self discovery of information, data, literature and clinical implications and manifestations

5. Supporting evidence, data, and patient presentation is provided as required by teachers and student tutorial members

6. Hypothesise potential answers and clinical solutions

7. Collect and disseminate new information applicable to clinical situation (Schmidt, 1983; Irby, 1994; Sutyak, Lebeau \& O'Donnell, 1998)

The success of teaching paradigms such as case based learning centres on the accomplishment of interactive tutorial groups as described in the 'seven-jump' process. In many cases, this is where the bulk of student learning takes place (as novices) - a place where students can assimilate, elaborate, debate and massage the theoretical content (thinking as experts) amongst themselves (Bennett, Harper \& Hedberg, 2002). Jonassen, Mayes and McAleese (1993) believe that using a case based learning approach allows learners to immerse themselves in meaningful learning and improved metacognitive processes.

\section{The case based learning process}

Undertaking case based learning in an online environment has similarities to traditional face to face teaching; however there are particular nuances that require teachers to be cognisant of and make the appropriate alterations to their practice (Silk, Agresta \& Weber, 2006). Within the BEH degree, the clinical units use a case based learning method in a blended teaching and learning approach, with face to face lectures and online learning via Blackboard. Other units in the degree use differing levels of educational technology, ranging from sophisticated communication systems to digital repositories and simple email. Real time or 'live' communication strategies are used by the author (Williams, 2006) to broaden student experiences (VoIP and Internet video conferencing). Using an e-learning approach allows the author to provide an interesting, flexible and interactive way of presenting realistic clinical cases, 
although when used by untrained educators, e-learning can be risky to one's teaching approach, and recently has been referred in the literature as Digital hemlock (Brabazon, 2002).

Contributions to the case based learning approach include writing authentic clinical scenarios that introduce students to a patient with a presenting clinical issue. This reinforces the notion of case based learning and enhances clinical praxis (Bowen, 1998; Herrington, Oliver \& Reeves, 2003; Cook, Thompson, Thomas, Thomas \& Pankratz, 2006; Silk, Agresta \& Weber, 2006). Increasing clinical praxis for the paramedic discipline is presently important given the contraints being placed on the health sector (Willis, Pointon, O'Meara, McCarthy \& Jensen 2009). It is hoped that the simulated cases will provide students with orientation and familarity with the cases they are likely to encounter during completing clinical placements. Each student undertakes approximately 4-6 weeks of clinical placements in a variety of health care settings, both acute and non-acute. This view is reinforced by Bennett, Harper and Hedberg (2002) who added, 'In designing learning environments to support these authentic activities there must be an alignment between the context in which learning is presented in the formal setting and the real life setting in which that knowledge can be called upon' (p.1). Further information about the clinical case is provided, including medical literature (supportive and controversial), vital signs, clinical manifestions and laboratory results.

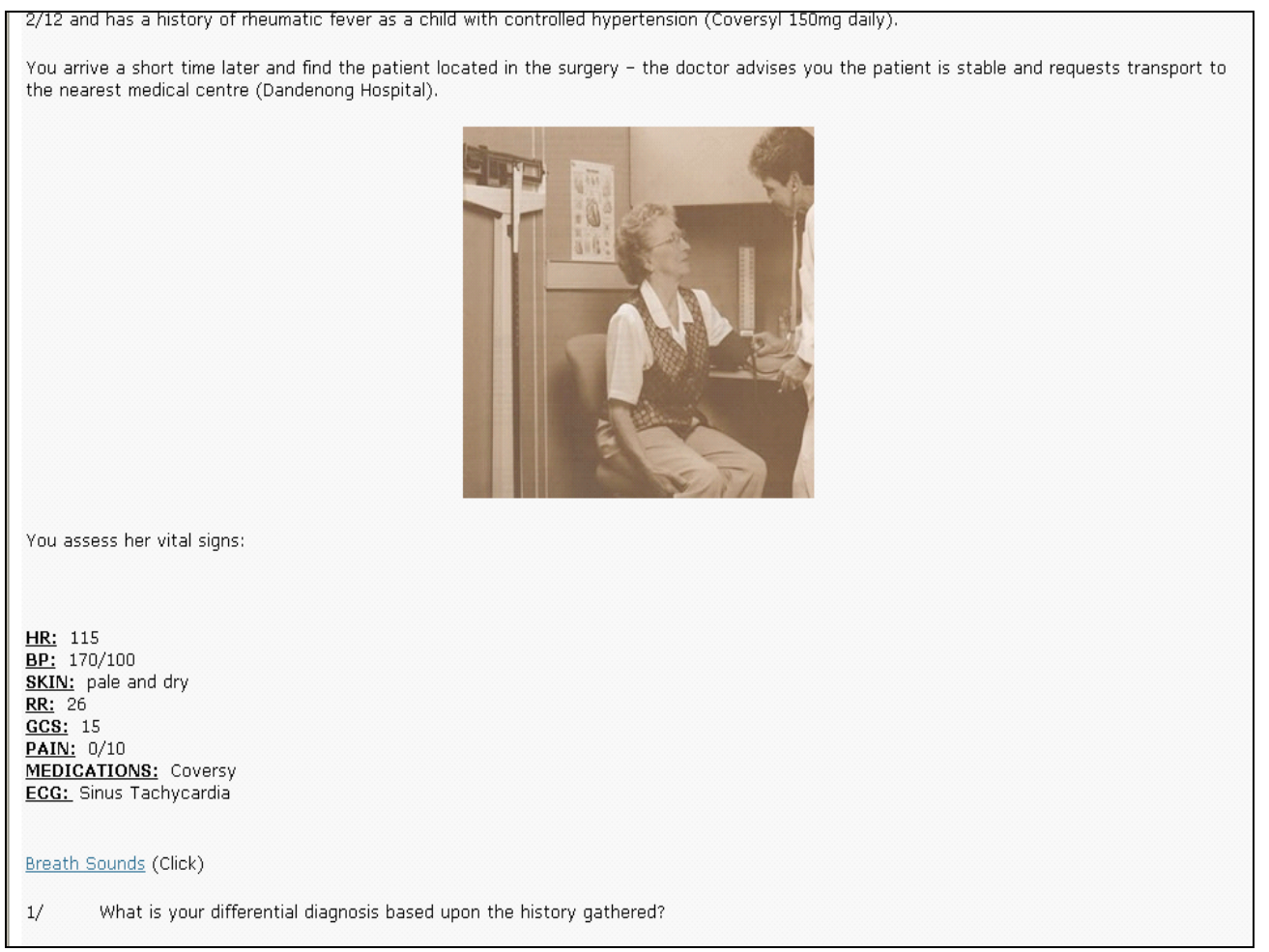

Figure 1: Example of clinical case presented in Blackboard

Cases were presented in "web page" format to each e-tutorial group in Blackboard (see Figure 1). Students were given between 8-10 cases and additional learning resources 
per semester, organised around the students' 6 hours per week contact time. Weekly face to face lectures took place on Mondays and Thursdays. Each case reflected the theoretical content and was uploaded following the Monday lecture, allowing students to undertake the case based learning approach prior to the Thursday lecture. Emoderation was structured around the 'Seven-Jump' process, whereby responsive moderation of e-tutorial discussion threads and answering of queries and linkage to relevant learning resources could be made, thus providing scaffolding and individualised learning where possible. Each case was 'closed' on each Sunday, although students had online access to cases and discussions for revision purposes.

\section{Integration of small e-tutorial groups}

Each year level of the BEH involved in the study was divided up into three separate etutorial groups within Blackboard. Depending on the year level, each e-tutorial group contained between 10 and 25 students. Without the use of Blackboard and associated technological support, the e-learning communities would not have been well supported throughout the learning process. The formation of tutorial groups particularly constructed in the e-learning environment is supported by Vygotsky's (1978) social theory, which claims that much of our intellectual development has direct correlation to the social interactions and group dynamics of such learning environments. This theory supports the concept that a group's perspectives and explanations to problems are reinforced through debate, disagreement, negotiation, discussion, and compromise (Thousand, et al. 1994). All of these behaviours occur within a case based learning context. Students are provided with case based learning orientation during weeks one and two outlining the learning outcomes and aims of using such an approach.

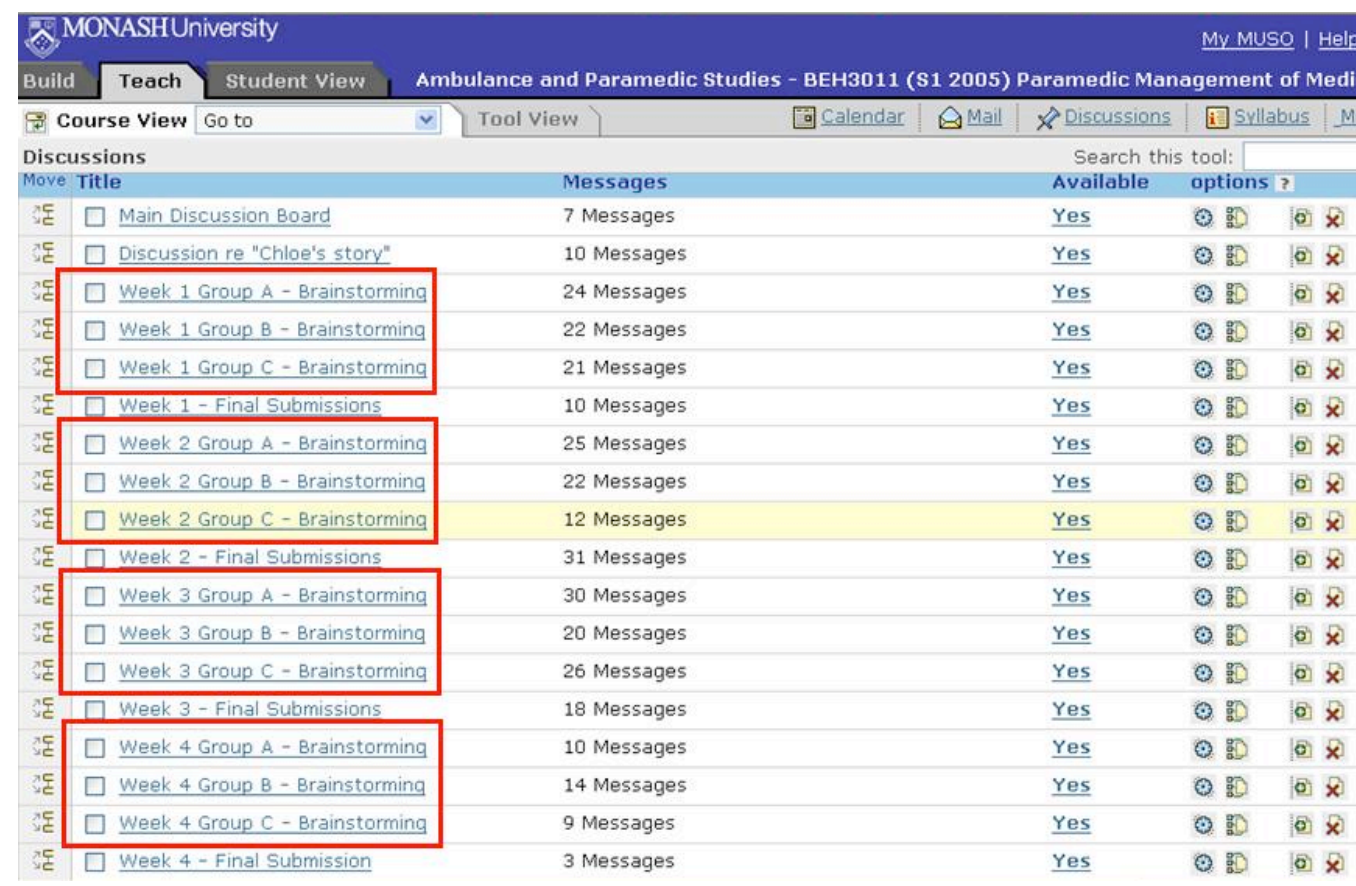

Figure 2: Screen picture - quarantined e-tute groups 
Each group's discussion was quarantined from the discussions of other e-groups (see Figure 2), allowing each group to have private discussions amongst themselves. This strategy stemmed from the author's previous experience and student feedback, indicating that student saturation of questions and answers occurred on frquently and some students 'took over' or dominated their own e-tutorial group, with negative consequences for fellow learners. In theory (and practice), this process is identical to a small number of student/s consistently answering all questions in a face to face classroom situation. While student numbers increased over the 3 year period, cases and learning resources did not vary substantially.

This study was undertaken over a 3-year period, comparing second and third year $\mathrm{BEH}$ paramedic undergraduate students, guided by the following research questions:

1. What are the perceptions and attitudes as members of a case based learning process?

2. How did students perceive case based learning in a blended teaching and learning environment?

\section{Methodology}

\section{Design}

A cross-sectional survey design was adopted in this study. This approach was undertaken in one phase at the conclusion of the first semester of three academic years during 2005, 2006, and 2007.

\section{Participants}

A convenience sample of paramedic students enrolled in the second or third years of the BEH participated in the study. Inclusion criteria included being enrolled at Monash University in the Department of Community Emergency Health and Paramedic Practice, and consenting to take part in the study. There were no specific exclusion criteria. Ethics approval for the study was granted by the Monash University Standing Committee on Ethical Research in Humans. Paramedic students from three consecutive cohorts were recruited to take part in the study.

\section{Instrumentation}

Quantitative data was obtained via a paper based, standardised self report questionnaire, developed to assess the students' attitudes to case based learning. The questionnaire was adapted from Engel and Hendricson (1994) with a 4-point Likert scale, ' 1 ' being 'strongly agree' and ' 4 ' being 'strongly disagree'. Data was also collected through open ended questions, such as 'what did you enjoy about case based learning' and 'what did you not enjoy about case based learning'.

\section{Data analysis}

Statistical analysis was undertaken using the Statistical Package for the Social Sciences Version 15.0 (SPSS). Descriptive statistics and independent sample $t$-test were used to describe and compare the demographics of the groups, with means and standard deviation used to summarise the responses to each question. Medians were used to describe the students' ages. The results are considered statistically significant if the $p$ value was $<0.05$ and all tests are 2-tailed unless otherwise stated. 


\section{Procedures}

Second and third year paramedic students were informed about the study via an explanatory letter distributed to them at the end of lecture during the final weeks of classes during semester one. Data was collected by a non-teaching staff member and returned to the primary investigator

\section{Results}

\section{Participants}

There were 247 questionnaires completed, an overall response rate of $74 \%$. Student participant group comprised all undergraduate students enrolled in second and third year groups throughout the BEH degree during the 2005, 2006, and 2007 academic years. The students' ages ranged considerably between the second and third year cohorts. Second year students ranged from 19-38 years (median 28.5 years). Third year students ranged from $20-53$ years (median 30.5 years). The paramedic program has a higher proportion of female undergraduate students enrolled in the degree (Table 1). This is discordant with historical levels of employment in the paramedic sector, which has been traditionally dominated by male employees.

Table 1: Student demographics $(\mathrm{n}=247)$

\begin{tabular}{|l|l|c|c|}
\hline \multicolumn{2}{|c|}{ Demographic } & $\%$ & $\mathrm{n}$ \\
\hline \multirow{3}{*}{ Gender } & Female & $67.2 \%$ & 166 \\
\cline { 2 - 4 } & Male & $32.8 \%$ & 81 \\
\hline \multirow{3}{*}{ Age } & $<24$ years & $54.7 \%$ & 135 \\
\cline { 2 - 4 } & 25-44 years & $41.3 \%$ & 102 \\
\cline { 2 - 4 } & 45-64 years & $4.0 \%$ & 10 \\
\hline
\end{tabular}

\section{Quantitative results}

The impact of case-based learning on interactions between teaching staff and students and amongst the students themselves produced some similar results. The majority of students (74\%) agreed or strongly agreed that the discussion sessions facilitated interaction between teaching staff and students, and $80 \%$ of students agreed or strongly agreed that case based learning fostered more beneficial interaction between classmates. In terms of improved communication between students and lecturing staff, $61 \%$ of the students agreed or strongly agreed that case based learning encouraged more communication between students and educational staff, whilst almost $38 \%$ disagreed with this statement.

The vast majority of students (97\%) agreed or strongly agreed that the patient related cases were well organised and the efficacy of case based learning when presenting case related material was also well supported by the students, with the majority $(78 \%)$ of students agreeing or strongly agreeing that case based learning was an effective way of presenting material, with the remaining students neither agreeing nor disagreeing with this statement.

The bulk of students (84\%) also agreed or strongly agreed that case based learning helped to improve their diagnostic skills and lateral thinking abilities. In terms of the development of clinical treatment plans, 79\% of students agreed or strongly agreed that case based learning improved the ability to develop treatment plans. Almost nine out of ten $(89 \%)$ students agreed or strongly agreed that case based learning made their 
learning experience more enjoyable. A reasonable proportion $(21 \%)$ reported that case based learning did not suit their learning style, in contrast to $78 \%$ of students, who agreed or strongly agreed that case based learning suited the way they learnt. The combined results and comparative data are presented in Tables 2-4.

Table 2: Combined survey results from three cohorts of paramedic students: 2005, 2006, $2007(\mathrm{n}=247)$

\begin{tabular}{|c|c|c|c|c|c|c|c|}
\hline & $\begin{array}{l}\text { Strongly } \\
\text { agree } \\
(\%)\end{array}$ & $\begin{array}{c}\text { Agree } \\
(\%)\end{array}$ & $\begin{array}{l}\text { Dis- } \\
\text { agree } \\
(\%)\end{array}$ & $\begin{array}{l}\text { Strongly } \\
\text { disagree } \\
(\%)\end{array}$ & \begin{tabular}{|l|l} 
Mean \\
rating \\
score
\end{tabular} & SD & Sig. \\
\hline The cases were well organised & 40.5 & 56.7 & 1.6 & 1.2 & 1.64 & .582 & NS \\
\hline $\begin{array}{l}\text { The discussion sessions facilitated } \\
\text { interaction between staff and students }\end{array}$ & 30.8 & 43.7 & 14.6 & 10.9 & 2.06 & .944 & ** \\
\hline $\begin{array}{l}\text { Case based learning made the learning } \\
\text { experience enjoyable }\end{array}$ & 30.0 & 59.1 & 6.9 & 4.0 & 1.85 & .714 & NS \\
\hline $\begin{array}{l}\text { Case based learning was an effective way } \\
\text { of presenting the material }\end{array}$ & 26.3 & 52.6 & 11.7 & 9.3 & 2.04 & .869 & \\
\hline $\begin{array}{l}\text { Case based learning fostered more } \\
\text { beneficial interaction between classmates }\end{array}$ & 23.9 & 56.7 & 12.1 & 7.3 & 2.03 & .808 & NS \\
\hline $\begin{array}{l}\text { Case based learning facilitated more } \\
\text { communication between students and } \\
\text { lecturing staff }\end{array}$ & 17.8 & 44.1 & 24.3 & 13.8 & 2.34 & .927 & NS \\
\hline Case based learning suited the way I learn & 23.1 & 55.1 & 12.1 & 9.7 & 2.09 & .858 & NS \\
\hline $\begin{array}{l}\text { Case based learning helped to improve } \\
\text { my diagnostic skills and lateral thinking }\end{array}$ & 30.4 & 54.3 & 10.5 & 4.9 & 1.90 & .772 & NS \\
\hline $\begin{array}{l}\text { Case based learning improved my ability } \\
\text { to treatment plans }\end{array}$ & 21.9 & 57.9 & 14.6 & 5.7 & 2.04 & .769 & NS \\
\hline $\begin{array}{l}\text { This teaching method is a useful } \\
\text { preparation in clinical problem solving }\end{array}$ & 37.2 & 56.3 & 4.9 & 1.6 & 1.71 & .634 & ** \\
\hline
\end{tabular}

NS $=$ not significant. ${ }^{*} \mathrm{p}<0.05{ }^{* *} \mathrm{p}<0.01$

Table 3: 2005-2006 cohort results

\begin{tabular}{|c|c|c|c|c|c|c|c|}
\hline & \multicolumn{3}{|c|}{ 2nd years 2005} & \multicolumn{3}{|c|}{ 3rd years 2006} & \multirow{2}{*}{ Sig. } \\
\hline & $\mathrm{N}$ & $\mathrm{M}$ & SD & $\mathrm{N}$ & $\mathrm{M}$ & SD & \\
\hline The cases were well organised & 36 & 1.56 & .504 & 96 & 1.65 & .523 & NS \\
\hline $\begin{array}{l}\text { The discussion sessions facilitated interaction between } \\
\text { staff and students }\end{array}$ & 36 & 1.67 & .756 & 96 & 2.43 & 1.02 & $* *$ \\
\hline $\begin{array}{l}\text { Case based learning made the learning experience } \\
\text { enjoyable }\end{array}$ & 36 & 1.97 & .845 & 96 & 1.76 & .707 & NS \\
\hline $\begin{array}{l}\text { Case based learning was an effective way of presenting } \\
\text { the material }\end{array}$ & 36 & 1.86 & .798 & 96 & 2.47 & .951 & ** \\
\hline $\begin{array}{l}\text { Case based learning fostered more beneficial interaction } \\
\text { between classmates }\end{array}$ & 36 & 2.11 & 1.03 & 96 & 2.04 & .739 & NS \\
\hline $\begin{array}{l}\text { Case based learning facilitated more communication } \\
\text { between students and lecturing staff }\end{array}$ & 36 & 2.47 & 1.15 & 96 & 2.59 & .901 & NS \\
\hline Case based learning suited the way I learn & 36 & 2.17 & 1.08 & 96 & 2.07 & .811 & NS \\
\hline $\begin{array}{l}\text { Case based learning helped to improve my diagnostic } \\
\text { skills and lateral thinking }\end{array}$ & 36 & 1.89 & .887 & 96 & 1.99 & .840 & NS \\
\hline $\begin{array}{l}\text { Case based learning improved my ability to treatment } \\
\text { plans }\end{array}$ & 36 & 2.03 & 1.00 & 96 & 2.06 & .751 & NS \\
\hline $\begin{array}{l}\text { This teaching method is a useful preparation in clinical } \\
\text { problem solving }\end{array}$ & 36 & 1.69 & .624 & 96 & 1.69 & .701 & NS \\
\hline
\end{tabular}

NS $=$ not significant. ${ }^{* *} \mathrm{p}<0.01$ 
Table 4: 2006-2007 cohort results

\begin{tabular}{|c|c|c|c|c|c|c|c|}
\hline & 2nd & jears & 2006 & & year & 2007 & \\
\hline & $\mathrm{N}$ & $\mathrm{M}$ & SD & $\mathrm{N}$ & $\mathrm{M}$ & SD & Sig \\
\hline The cases were well organised & 45 & 1.58 & .543 & 70 & 1.70 & .709 & NS \\
\hline $\begin{array}{l}\text { The discussion sessions facilitated interaction between } \\
\text { staff and students }\end{array}$ & 45 & 1.87 & .786 & 70 & 1.87 & .850 & NS \\
\hline $\begin{array}{l}\text { Case based learning made the learning experience } \\
\text { enjoyable }\end{array}$ & 45 & 1.82 & .576 & 70 & 1.93 & .729 & NS \\
\hline $\begin{array}{l}\text { Case based learning was an effective way of presenting } \\
\text { the material }\end{array}$ & 45 & 1.69 & .596 & 70 & 1.77 & .685 & NS \\
\hline $\begin{array}{l}\text { Case based learning fostered more beneficial interaction } \\
\text { between classmates }\end{array}$ & 45 & 1.91 & .701 & 70 & 2.04 & .842 & NS \\
\hline $\begin{array}{l}\text { Case based learning facilitated more communication } \\
\text { between students and lecturing staff }\end{array}$ & 45 & 2.07 & .720 & 70 & 2.10 & .854 & NS \\
\hline Case based learning suited the way I learn & 45 & 1.93 & .654 & 70 & 2.16 & .911 & * \\
\hline $\begin{array}{l}\text { Case based learning helped to improve my diagnostic } \\
\text { skills and lateral thinking }\end{array}$ & 45 & 1.82 & .535 & 70 & 1.83 & .742 & NS \\
\hline $\begin{array}{l}\text { Case based learning improved my ability to treatment } \\
\text { plans }\end{array}$ & 45 & 2.07 & .618 & 70 & 2.00 & .761 & NS \\
\hline $\begin{array}{l}\text { This teaching method is a useful preparation in clinical } \\
\text { problem solving }\end{array}$ & 45 & 1.78 & .471 & 70 & 1.70 & .645 & NS \\
\hline
\end{tabular}

NS $=$ not significant ${ }^{*} \mathrm{p}<0.05$

\section{Qualitative analysis results}

Student responses to open ended questions underwent thematic analysis as described by Bender and Ewbank (1994) by three independent, experienced qualitative researchers, and the results compared between data sets. These multiple coding approaches or credibility checks are one aspect argued to increase the objectivity and trustworthiness of qualitative research (Elliot, Fischer \& Rennie, 1999; Barbour 2001). Data was triangulated with member checking and the thematic analysis of the written data was achieved until saturation was achieved (i.e. no new themes emerged). A sample of typical responses from second and third year students from 2005-2007 is shown below, discussing their perceptions of communication/ interaction, workload, computer equity and learning styles:

\section{Communication and interaction}

That it can be dominated by 1 or 2 people in a group setting (BEH 3rd year student [14])

I really enjoyed smaller groups to discuss ideas with my colleagues (BEH 2nd year student [8])

Great interaction between the student and the lecturer and gave us an opportunity to raise any queries (BEH 2nd year student [17])

Usually one or two people with prior knowledge dominated the case and it was often difficult to contribute (BEH 3rd year student [20])

\section{Workload}

Too much to read sometimes" (BEH 3rd year student [4])

Online CBL work was difficult to find time for and difficult to complete on time (BEH 2nd year student [4]) 
CBL had a very high demand on time and to be online (BEH 2nd year student [9])

Increased demands on my time and work also made it difficult to participate (BEH 3rd year student [12])

Time restraints also make it hard to participate in the online tute (BEH 3rd year student [8])

Should have allocated time during week for us to complete (BEH 3rd year student [10])

\section{Computer equity}

I don't have Internet at home and found it slightly difficult to access information (BEH 2nd year student [23])

All on computer - without Internet access at home, often others had answered all questions overnight before I had a chance to look at the case at all (BEH 3rd year student [21])

Can disadvantage some students if no computer at home (BEH 3rd year student [1])

Limited access to Internet (BEH 2nd year student [30])

As I do not have access to the internet at home during the week it was often difficult to participate (BEH 2nd year student [33])

\section{Learning styles}

I personally found it a much more effective way of learning (BEH 3rd year student [11])

It improves my memory for clinical knowledge (BEH 2nd year student [3])

Great way to remember theory learnt in class (BEH 2nd year student [12])

It suited my learning style to have the information first then to put it into context (BEH 2nd year student [17])

Much better than individual learning in my opinion (BEH 3rd year student [9])

\section{Discussion}

\section{Interaction between students and group dynamics}

The basis to the constructivism framework implicates student-centredness and encourages students to find and self discover the information for themselves. This material should be meaningful to their learning needs whilst allowing them to construct new information and establishing social learning interactions with fellow students and teaching staff. These very concepts rely on student-to-student and student-to-instructor interactions. This enables students to listen to each others' views, think analytically, and provide constructive criticism based upon their own experiences in order to develop answers or solutions to the problem (Huda and Brula, 1999). Without these interactions this highlights a teacher defined teaching and learning environment which is in direct dissent with student centred learning principles (Chadwick, Bearn, Jack \& O'Brien, 2002). Group learning processes automatically assume to provide ample motivation to students, particularly in PBL centred programs (Dolmans, et al. 2005). 
The findings in this study suggested that communication and interactions between instructors and students has room for improvement in the case based learning environment. Several conclusions could be drawn from this. The first is that students were not used to the nature of case based learning, and therefore they could have been confronted by the very real need to 'interact' with each other. The longer the students spend time with each other, so does the likelihood of interacting forces cooperating in an environment which promotes individual competitive performances and the potential for personality and learning clashes (Dolmans, et al. 2001). Such an issue was made explicit in the third year group where certain students were 'taking over' in the e-tutorial group, thus hindering their learning experiences. Similar perceptions were reported by the student groups studied by Atack and Rankin (2002) and Dolmans et al. (2001), who were dissatisfied with the interactions, motivations, and cohesion with others. Other possible factors include difficulties for the author moderating and maintaining an efficient online classroom presence given large e-tutorial group numbers and the computer and Internet access issues for some students.

The literature interestingly balances the negative and positive aspects of student and group dynamics in relation to PBL. Papers by Dolmans et al. (2001) and VisschersPleijers et al. (2005) state that no evidence exists with regard to PBL and dysfunctional groups, however a significant amount of literature is available on difficult groups described by teaching staff. Pang et al. (2002) found attributes such as a lack of cooperation amongst students and also an ambivalence about whom they should develop learning group partnerships with. Pang et al. (2002) also found that students tended to be too independent and spent too much time on self directed study, which offset their co-learning with fellow colleagues. They were also able to show that some students encountered difficulties in personality clashes. Of note, the descriptive study by Das Carlos et al. (2003) also highlighted that the most prolific tutorial groups consisted of female group members. This compared to the male groups who were considered less productive and even, in some cases, unproductive.

Case based learning and other educational philosophies require positive, engaged and supportive student to student interactions (Dolmans, et al. 2005). This allows the teacher to act in a facilitator's role, not a dictator role, and allows students to be proactive in their learning. Huda and Brula (1999) draw attention to the well documented literature (Knowles, 1970; Barrows \& Tamblyn, 1980) supporting the significant benefits of small tutorial groups within PBL programs.

However it should be noted that the very notion of interdependence is not magically embedded nor embraced and supported in tutorial groups and has been strongly argued by Brown (1998) and Morris and Turnbull (2004). They argued that the elements of student centredness and interdependence cause conflict and tension amongst student groups undertaking such teaching and learning settings (Brown 1988; Morris \& Turnbull, 2004). Carpio, Illesca, Ellis, Crooks,, Droghetti, Tompkins \& Noesgaard (1999) support this, stating that 'self directed, small group learning is new to many students and may be inconsistent with their learning experiences or preferred learning styles' (p. 35). Dolmans et al. (2005) continue the argument and add that many staff and student groups have experienced dysfunctional colleagues or student groups, and suggest many studies have investigated this area supporting the view that dysfunctional group dynamics can and will occur.

Group interaction and dynamics has the potential to inhibit the effectiveness of PBL orientated group work. The pioneering work by Barrows (1986) on PBL described 
several key elements to ineffective group attributes: silence, sarcasm, free loading, arguments, and attempts at taking over group learning (Das Carlo, et al. 2003). In practice, group learning environments have been shown by other authors to be less successful (Dolmans, et al. 1996; Hitchcock \& Anderson 1997; De Grave, et al. 1999; Stromso, et al. 2004). Of note, 'free loading' and 'taking over' were elements described by the third year student cohorts in this study.

Several studies have attempted to establish positive group dynamics and interactions with learning outcomes (De Grave, et al. 1999; Pang, et al. 2002; Wigen, et al. 2003). This has also led researchers to investigate whether these positive group interactions were related to specific learning styles and if these interactions lead to better academic results (De Grave, et al. 1999; Wigen, et al. 2003). Papers by Dolmans et al. (1998), Iputo (1999), Schmidt et al. (1989) and Slavin (1996) described several positive factors in 'good' group dynamics - motivation, elaboration, cohesion, withdrawing, independence, reasoning skills, and active interaction. Dolmans et al. (2001) stated that 'The studies conducted so far provide empirical evidence that PBL enhances intrinsic motivation in subject matter and is more enjoyable' (p. 886). Of note, Visschers-Pleijers et al's (2004) paper was the only article located that focused on the cognitive interface in student group environments rather than simple group collaborations. They surmised that processes such as elaborations and co-constructions of knowledge were found in small group learning undertaking a PBL tutorial.

With a positive team/group environment, the amount of interdependent learning that takes place may improve. It is therefore reasonable to conclude that group and interpersonal dynamics can facilitate or hinder co-learning and cross-pollination of information and previous educational experience. This is reinforced by Botelho and O'Donnell (2001) and Perrine and Logan (2004) who support this proposition with the view that student to student interaction allows greater motivation thus stimulating greater understanding of concepts and the ability to seek out clarification of ideas or misunderstandings.

So what is the answer? Perhaps teachers should be applying a learning/personality inventory such as the Myer-Briggs (Briggs \& Myers, 1962) or Kolb (Kolb, 1984) inventories into student's personality traits prior to dividing students into random groupings? Could this reduce the likelihood of personality clashes and the development of such negative traits as highlighted by Barrows (1986) and Dolmans et al. (2001)? However, consideration should be given to the fact that this type of hostile environment may be considered the norm for the day to day paramedic work environment and thus this is providing them an opportunity to work, learn, and develop confounding ideas and arguments in a 'non-work' environment.

Student interactions between themselves and amongst teaching staff as discussed earlier is one of the hallmark attributes for a successful learning process. The literature indicates that the success of the respective programs and the amount of information retained by students is directly related to the dynamics of classroom/tutorial environments. This is also inversely proportional to the struggle associated with dysfunctional learner groups. The results of these specific data have highlighted one particular question - are student interactions/learner dynamics directly related to dissimilar learner styles or are they related to particular student cohorts progressing through the degree at the same time? 


\section{Communication between staff and students}

It is interesting to note the heterogeneity of the research findings between the year level groups. Whilst the students were overwhelmingly positive in their responses to discussion sessions facilitating interaction between teaching staff and students (74\%); when asked specifically about communication between fellow students and communication with teaching staff, their responses, whilst still generally positive, were not enthusiastic. These results are consistent with the randomised control study by Antepohl and Herzig (1999) who found that medical students were also uncertain if PBL improved their communication skills. One possible explanation for these modest findings could be the fact that it was the first semester for the second years undertaking this type of learning, and many may have been unfamiliar with the requirement for them to be self directed and autonomous in their learning, using less direct communication than in their previous experience. Conversely, third year students may have been more savvy with their online learning time management and less satisfied with the 'distance' often associated with online teaching and learning.

These findings are critical in the context of student centredness since the very success of its pedagogical values is shaped upon the very notion that students communicate effectively. They have the capacity to be self directed and motivated to learn individually or collaboratively with other students, whilst the teacher acts as a facilitator not as a knowledge dispenser. PBL and case based learning are rooted in a belief that communication between students, and between students and teaching staff is important, and that student centred strategies improve these processes. Interestingly, papers by Hay and Katsikitis (2001), Hubble and Richards (2006), Schmidt (1994) and Stromso (2004) identified that students within their study actually felt they required less interaction, communication and general expectations of their teachers as their PBL program continued through the semester. The student responses outlined above led the author to query whether this assumption is justified in all settings, and this question is worthy of further detailed examination.

The study undertaken by Pang et al. (2002) highlighted that students did not find teachers helpful in the PBL program and in many cases did not provide clear guidance and constructive and timely feedback. Positive teacher-student interaction has been identified as a key element to the PBL process. The studies by Choi (2003) and Atack and Rankin (2002) were able to highlight that students who received frequent feedback and communication experienced higher satisfaction levels. The balance between providing feedback and providing the direct knowledge and answers is fine, and is difficult within paradigms like case based learning.

The results indicate communication between students and faculty could have been improved. This is a difficult area, particularly in a case based learning environment. On the one hand, students understand they are expected to learn as autonomous thinkers and communicate with their fellow peers to seek answers and resources, whereas on the other, some students obviously feel more dialogue with the teaching staff could have assisted the case based learning process. There appears to be scope to undertake some form of learner analysis prior and during their undergraduate years, perhaps this will allow teaching staff to better inform themselves on how much communication is actually enough and if students have learnt in a student centred environment before. 


\section{Workload}

Analysis of qualitative data highlighted that workload was a consistent issue for both groups; however, this was more prominent in the third year group. Of interest though, was that this perception was not supported by the evidence in the Blackboard activity $\log$ of both student groups. The second year group actively participated in the online environment more often than their third year counterparts, yet it was the third year group who claimed that their workload was a hindrance. It should be pointed out that third year students undertook fewer units and assessments in semester one than the second years, with contact hours time also being reduced. The findings from this study suggest that some students felt that the case based learning process, particularly via the online learning medium, placed greater workload strain on their studies. Several studies identified similar workload issues to the findings in this study, and actually considered PBL programs to be time consuming (Atack \& Rankin, 2002; Pang, et al. 2002; Choi, 2003; McLinden, et al. 2006). The studies recognised that the paradigm of PBL imposed heavy workloads on students' daily study commitments that are in opposition with the idea that PBL programs are centred upon workload friendliness and provide students with the ability to shape their own timetable requirements to their learning needs. The authors argued that students felt they did not have enough time to complete their studies. The descriptive study by Tichon (2002) highlighted positive student perceptions with the PBL program offered via the Internet and not only allowed flexibility, greater interest but improved quality in learning standards in the curricula.

\section{Computer equity}

A major hurdle for web based programs is to avoid technological barriers which impair learning opportunities and thus may increase students and teachers' frustration (Choi, 2003). These may include advanced multimedia with correspondingly slow download times, insufficient time, and resistance to online learning (Cook \& Dupras, 2004). As identified in the specific responses by both student groups, computer equity is a teaching and learning variable that must be acknowledged, particularly in a blended teaching approach. Simply, if students do not have computer access or insufficiently high speed Internet access, then interactive web based discussions cannot take place and major learning opportunities may be lost. In Choi's (2003) study the student group felt that the Internet technology itself was a major disadvantage, especially for less computer literate students (Choi, 2003). Similar objections were raised in the qualitative themes where students had technological problems leading to a reduction in their participation. Other students did not have computer access at home, which applied extra pressure upon them and their participation. Again, the notion that e-learning is a panacea for students undertaking distance education is in some cases creating a dichotomy, with examples that this in fact is creating its own new distances. These findings were also found in the studies by Atack and Rankin (2002), Cragg, et al. (2003), Cook and Dupras (2004) who reinforced the concept that inadequate computer skills, the inability to access computers and failure to maintain connections were frustration perceptions and potential barriers to students' learning. The results from this study perhaps suggest that teaching and learning approaches using the Internet as the medium should perform a student's needs analysis to enable teachers to identify how many students have computer access, rather than accepting that they should. 
Whilst obvious benefits exist with distance education and e-learning approaches in terms of flexibility, timely feedback and possible cost savings to faculty and students, there is a need to be mindful that the technology does not 'drive' one's pedagogy and may in some aspects reduce the quality of teaching.

\section{Learning styles}

'If a student's learning style is mismatched with the teaching style or the learning environment, the effort needed to adapt may negatively affect the student's performance' (Curry, 1999). Research has suggested that learners tend to alter their learning styles soon after commencement of programs such as PBL. The study by Wigen et al (2003) recommended that students' learning style and preferences had adapted to the PBL format within a very short space of time. Similarly in Iputo's (1999) longitudinal study, medical students' learning style became more adaptive and versatile as the PBL orientated degree progressed, suggesting the students for one reason or another manipulated their learning needs into the paradigm of PBL.

The BEH students' responses suggest that in many cases case based learning suited their learning styles. However, these data may simply be a reflection of the particular characteristics of these undergraduate paramedic students (for example, age and preconceived ideas about the structure and role of teaching and learning in higher education), and short exposure to case based learning principles do not allow the author to generalise findings to other disciplines and settings. Comparable results were found in research by McParland, Noble and Livingston (2004) who found student's learning styles were not altered nor completely embraced by the PBL curriculum.

The descriptive comparative study by Carpio et al. (1999) attempted to identify the learning styles of student and teaching staff. Their study concluded several key elements, which are parallel to this case based learning research project. Firstly, they suggested that with the changing student population in terms of age, gender, prior knowledge, it would be remiss for faculty staff not to re-examine their students' learning styles prior to engaging in their programs. This educational principle is supported by several authors (Cook \& Dupras, 2004; Yang and Cornelious, 2005), who also encourage teaching staff to undertake learning style inventories on their student groups. Secondly, Carpio et al. (1999) conclude that identification of the students' learning needs allowed a greater perception from the students on the vital elements to group and independent learning. Finally, they discuss the importance of not only assessing their students' learning styles but their own teaching staff. They suggest that unknowingly, teachers will automatically teach according to their own learning style, which may be incongruent with the students' learning preferences. This is reinforced by the study by Schoenfeld-Tacher et al. (2005) who observed teachers vary their teaching styles according to their own learning styles.

Antepohl and Herzig's (1999) study of medical students found that the majority of students preferred PBL as it suited their learning styles. The meta-analysis by Vernon and Blake (1993) found that approximately $10 \%$ of students performed better academically whilst undertaking a PBL program, compared with standard students, although other studies (Albanese \& Mitchell, 1993; Berkson, 1993) have suggested that little or no effect occurs upon students' academic achievement. Similar research (Coles, 1985; Newble \& Clarke, 1986) reported that medically trained students educated under different teaching methodologies used a predominant inclination towards 
constructivism. Students tended to perform better and retain knowledge and skills when they could construct their own learning needs within the subject context (Wigen, et al. 2003).

This study did not formally assess students' learning style prior to teaching engagement. Based upon the literature and critical reflection as a teacher, perhaps teaching staff (including the author) should be assessing their own and students' learning styles prior to any teaching engagement. This is probably more important where teaching strategies use online environments (Cook \& Dupras, 2004).

\section{Limitations of study}

A number of limitations emerged during this study that demand particular discussion. These include the small sample size available from the convenience sample and the inability to make power calculations. Also, the instrument used in this study requires further psychometric assessment to assess internal consistency and construct validity. The study does not identify past clinical teaching and learning experiences, or experiences as clinical health care workers (e.g. nurses, physiotherapy or nonemergency paramedic attendants). These specific professional learning background details may have affected the results. The researcher also brought his own personal views, experiences and expectations into the qualitative analysis.

Overall, the findings of this study cannot be taken to be representative of lecturing staff teaching case based learning programs at large, rather they offer the experiences of this particular group of individuals, but they do provide new levels of understanding of paramedic programs which is important in this specific area of health science education.

\section{Conclusion}

This study set out to explore the perceptions of undergraduate students being taught using a case based learning model, by addressing several main key questions. These questions were adapted to provide a contemporary description of undergraduate student perceptions of case based learning and the use of blended teaching methods. Presently, case based learning appears to be a useful and enjoyable teaching and learning tool for students enrolled in the undergraduate paramedic BEH program. However, some of the main tenets of case based learning such as student-faculty communication and interaction produced some conflicting results. The findings of this study also suggest that further research should be promoted in other areas of paramedic education including similar studies with other universities and health care providers.

\section{Acknowledgment}

I would like to acknowledge the feedback provided by Ted Brown and Malcolm Boyle in developing this manuscript.

\section{References}

Albanese, M. (2000). Problem-based learning: Why curricula are likely to show little effect on knowledge and clinical skills. Medical Education, 34(4), 729-738. 
Albanese, M. A. \& Mitchell, S. (1993). Problem-based learning: A review of literature on its outcomes and implementation issues. Academic Medicine, 68(1), 52-81.

Antepohl, W. \& Herzig, S. (1999). Problem-based learning versus lecture-based learning in a course of basic pharmacology: A controlled, randomized study. Medical Education, 33(2), 106113.

Atack, L. \& Rankin, J. (2002). A descriptive study of registered nurses' experiences with webbased learning. Journal of Advanced Nursing, 40(4), 457-465.

Barbour, R. (2001). Checklists for improving rigour in qualitative research: A case of the tail wagging the dog? British Medical Journal, 322(7294), 1115-1117.

Barrows, H. (1986). A taxonomy of problem-based learning methods. Medical Education, 20(6), 481-486.

Barrows, H. \& Tamblyn, R. (1980). Problem-based learning: An approach to medical education. New York, Springer Publishing Company.

Bender, D. \& Ewbank, D. (1994). The focus group as a tool for health research: Issues in design and analysis. Health Transition Review, 4(1), 63-79.

Bennett, S., Harper, B. \& Hedberg, J. (2002). Designing real life cases to support authentic design activities. Australian Journal of Educational Technology, 18(1), 1-12. http: / / www.ascilite.org.au/ajet/ajet18/bennett.html

Berkson, L. (1993). Problem-based learning: Have the expectations been met? Academic Medicine, 68(10 Suppl), S79-S88.

Bowen, D. (1998). Integrating case-based instruction into dental hygiene curricula. Journal of Dental Education, 62(3), 253-256.

Brabazon, T. (2002). Digital hemlock: Internet education and the poisoning of teaching. Sydney, UNSW Press.

Briggs, K. \& I. Myers (1962). Manual: A guide to the development and use of the Myers-Briggs Type Indicator. California, Consulting Psychologists Press.

Brown, R. (1988). Group processes: Dynamic within and between groups. Oxford, Blackwell.

Bruner, J. (1966). Toward a theory of instruction. Cambridge, Harvard University Press.

Carpio, B., Illesca, M., Ellis, P., Crooks, D., Droghetti, J., Tompkins, C. \& Noesgaard, C. (1999). Student and faculty learning styles in a Canadian and a Chilean self-directed, problem-based nursing program. Canadian Journal of Nursing Research, 31(3), 31-50.

Chadwick, S. M., Bearn, D. R., Jack, A. C. \& O'Brien, K. D. (2002). Orthodontic undergraduate education: Developments in a modern curriculum. European Journal of Dental Education, 6(2), 57-63.

Choi, H. (2003). A problem-based learning trial on the Internet involving undergraduate nursing students. Journal of Nursing Education, 42(8), 359-363.

Coles, C. (1985). Differences between conventional and problem-based curricula in their students' approaches to studying. Medical Education, 19(4), 308-309.

Cook, D. A., Thompson, W. G., Thomas, K. G., Thomas, M. R. \& Pankratz, V. S. (2006). Impact of self-assessment questions and learning styles in web-based learning: A randomized, controlled, crossover trial. Academic Medicine, 81(3), 231-238. [verified 14 Jul 2009] http: / / journals.lww.com/academicmedicine / Fulltext/2006/03000/Impact_of_Self_Assess ment_Questions_and_Learning.5.aspx 
Cook, D. A. \& D. M. Dupras (2004). A practical guide to developing effective web-based learning. Journal of General Internal Medicine, 19(6), 698-707.

Cragg, C. E., Edwards, N., Yue, Z., Xin, S. L. \& Hui, Z. D. (2003). Integrating Web-based technology into distance education for nurses in China: computer and Internet access and attitudes. CIN: Computers, Informatics, Nursing, 21(5), 265-274.

Curry, L. (1999). Cognitive and learning styles in medical education. Academic Medicine, 74(4), 409-413.

Das Carlo, M., Swadi, H. \& Mpofu, D. (2003). Medical student perceptions of factors affecting productivity of problem-based learning tutorial groups: Does culture influence the outcome? Teaching \& Learning in Medicine, 15(1), 59-64.

De Grave, W. S., Dolmans, D. H. \& van der Vleuten, C. P. (1999). Profiles of effective tutors in problem-based learning: Scaffolding student learning. Medical Education, 33(12), 901-906. [verified 15 Jul 2009] http:/ / www.fdg.unimaas.nl/educ/ cees/CV/Publications/1999/Profiles $\% 20$ of $\% 20$ effective $\% 20$ tutors $\% 20$ in $\% 20$ problem-based $\% 20$ learning.pdf

Dewey, J. (1916). Demoracy and Education. An introduction to the philosophy of education. New York, Free Press.

Dolmans, D. H., De Grave, W., Wolfhagen, I. H. \& van der Vleuten, C. P. (2005). Problem-based learning: Future challenges for educational practice and research. Medical Education, 39(7), 732-741.

Dolmans, D. H., Wolfhagen, I. H. \& Schmidt, H. G. (1996). Effects of tutor expertise on student performance in relation to prior knowledge and level of curricular structure. Academic Medicine, 71(9), 1008-1011.

Dolmans, D. H., Wolfhagen, I. H. \& van der Vleuten, C. P. (2001). Why aren't they working? In P. Schwartz, S. Mennin \& G. Webb (Eds), Problem-based learning. London, Kogan Page.

Dolmans, D. H., Wolfhagen, I. H., van der Vleuten, C. P. \& Wijnen, W. H. (2001). Solving problems with group work in problem-based learning: Hold on to the philosophy. Medical Education, 35(9), 884-889.

Elliot, R., Fischer, C. \& Rennie, D. (1999). Evolving guidelines for publication of qualitative research studies in psychology and related studies. British Journal of Clinical Psychology, 38(3), 215-229.

Engel, F. \& Hendricson, W. (1994). A case-based learning model in orthodontics. Journal of Dental Education, 58(10), 762-777.

Herrington, J., Oliver, R. \& Reeves, T. C. (2003). Patterns of engagement in authentic online learning environments. Australian Journal of Educational Technology, 19(1), 59-71. http:/ / www.ascilite.org.au/ajet/ajet19/herrington.html

Hitchcock, M. \& Anderson, H. (1997). Dealing with dysfunctional tutorial groups. Teaching $\mathcal{E}$ Learning in Medicine, 9(1), 19-24.

Huda, N. \& Brula, A. Q. (1999). An introductory course on study skills forming a bridge between traditional and problem based learning (PBL). JPMA - Journal of the Pakistan Medical Association, 49(2), 27-30.

Iputo, J. E. (1999). Impact of the problem-based learning curriculum on the learning styles and strategies of medical students at the University of Transkei. South African Medical Journal, $89(5), 550-554$ 
Irby, D. (1994). Three exemplary models of case-based teaching. Academic Medicine, 69(12), 947953.

Jonassen, D., Mayes, T. \& McAleese, R. (1993). A manifesto for a constructivist approach to uses of technology in higher education. In T.M. Duffy, J. Lowyck \& D.H. Jonassen (Eds), Designing environments for constructive learning (pp. 231-247). Heidelberg: Springer-Verlag

Knowles, M. (1970). The modern practice of adult education. Andragogy versus pedagogy. New Jersey, Prentice Hall/Cambridge.

Kolb, D. (1984). Experiential learning: Experience as the source of learning and development. New Jersey, Prentice-Hall.

McLinden, M., McCall, S., Hinton, D. \& Weston, A. (2006). Participation in online problem based learning: Insights from postgraduate teachers studying through open and distance education. Distance Education, 27(3), 331-353.

McParland, M., Noble, L. M. \& Livingston G. (2004). The effectiveness of problem-based learning compared to traditional teaching in undergraduate psychiatry. Medical Education, 38(8), 859867.

Morris, D. \& Turnbull, P. (2004). Using student nurses as teachers in inquiry-based learning. Journal of Advanced Nursing, 45(2), 136-144.

Newble, D. I. \& Clarke, R. M. (1986). The approaches to learning of students in a traditional and in an innovative problem-based medical school. Medical Education, 20(3), 267-273.

Pang, S. M., Wong, T. K., Dorcas, A., Lai, C. K., Lee, R. L., Lee, W. M. \& Mok, E. S. (2002). Evaluating the use of developmental action inquiry in constructing a problem-based learning curriculum for pre-registration nursing education in Hong Kong: A student perspective. Journal of Advanced Nursing, 40(2), 230-41.

Piaget, J. (1968). Six psychological studies. New York, Vintage Books.

Reay, J. (2001). Blended learning - a fusion for the future. Knowledge Management Review, 4(3), 6.

Schmidt, H. G. (1983). Problem-based learning: Rationale and description. Medical Education, 17(1), 11-16.

Schoenfeld-Tacher, R., Bright, J., McConnell, S. L., Marley, W. S. \& Kogan L. R. (2005). Webbased technology: Its effects on small group "problem-based learning" interactions in a professional veterinary medical program. Journal of Veterinary Medical Education, 32(1), 86-92.

Silk, H., Agresta, T. \& Weber, C. M. (2006). A new way to integrate clinically relevant technology into small-group teaching. Academic Medicine, 81(3), 239-244.

Strømsø, H.I., Grøttum, P. \& Lycke K. H. (2004). Changes in student approaches to learning with the introduction of computer-supported problem-based learning. Medical Education, 38(4), 390-398.

Sutyak, J. P., Lebeau, R. B. \& O'Donnell, A. M. (1998). Unstructured cases in case-based learning benefit students with primary care career preferences. The American Journal of Surgery, 175(6), 503-507.

Thousand, J. S., Villa, R. A. \& Nevin, A. I. (1994). Creativity and collaborative learning: A practical guide to empowering students and teachers. Baltimore, Brookes.

Tichon, J. G. (2002). Problem-based learning: A case study in providing e-health education using the Internet. Journal of Telemedicine E Telecare, 8(Suppl 3), S3:66-68. 
Van Dijken, P. C., Thevoz, S., Jucker-Kupper, P., Feihl, F., Bonvin, R. \& Waeber, B. (2008). Evaluation of an online, case-based interactive approach to teaching pathophysiology. Medical Teacher, 30(5), 131-136.

Vernon, D. T. \& Blake, R. L. (1993). Does problem-based learning work? A meta-analysis of evaluative research. Academic Medicine, 68(7), 550-63.

Visschers-Pleijers, A. J., Dolmans, D. H., Wolfhagen, I. H. \& van der Vleuten, C. P. (2004). Exploration of a method to analyze group interactions in problem-based learning. Medical Teacher, 26(5), 471-478.

Vygotsky, L. (1978). Mind in society. London, Harvard University Press.

Wigen, K., Holen, A. \& Ellingsen, O. (2003). Predicting academic success by group behaviour in PBL. Medical Teacher, 25(1), 32-37.

Williams, B. (2006). Using creative and contemporary teaching strategies to promote emancipation, empowerment and achievement in undergraduate paramedic students - a personal reflection. Journal of Emergency Primary Health Care, 4(2). [verified 14 Jul 2009] http: / / www.jephc.com/full_article.cfm?content_id=362

Willis, E., Pointon, T., O’Meara, P., McCarthy, C. \& Jensen, A. L. (2009). Paramedic education: Developing depth through networks and evidence-based research. Australian Learning and Teaching Council. [verified 14 Jul 2009] http: / / www.altc.edu.au/system/files / resources/DS7-616\%20Paramedic\%20education\%20March\%202009.pdf

Yang, Y. \& Cornelious, L. (2005). Preparing instructors for quality online instruction. Online Journal of Distance Learning Administration, 8(1).

http:// www.westga.edu/ distance/ojdla/spring81/yang81.htm

Mr Brett Williams, Senior Lecturer

Department of Community Emergency Health \& Paramedic Practice

Monash University, PO Box 527, Frankston, Victoria 3199, Australia

Email: brett.williams@med.monash.edu.au

Web: http:/ / www.med.monash.edu.au/cehpp/ 